\title{
Perubahan Karakteristik Bahan Pangan pada Keripik Buah dengan Metode Freeze Drying (Review)
}

\author{
Nur Ahmad Habibi ${ }^{1^{*}}$, Sarah Fathia ${ }^{2}$, Citra Tristi Utami ${ }^{3}$ \\ ${ }^{1}$ Departemen Teknologi Pangan, Institut Pertanian Bogor \\ ${ }^{2}$ Departemen Ilmu Gizi, Universitas Diponegoro \\ *E-mail: nurahmadhabibi95@gmail.com
}

\begin{abstract}
Food processing is changing from thermal to non thermal process nowadays for non thermal process could maintain food quality including sensory and nutrition value. Freeze drying is a non thermal drying method using low temperature.The water content of the product is frozen from the water phase to ice phase and into gas phase (sublimation process) to control the pressure and temperature. There are some changes in food characteristic in fruit chips processing using freeze drying method. In the physical characteristic are geometry, mechanic, optical, and other physical value changes. In the sensory characteristic, freeze drying method could maintain food colour, flavour, texture and odor(aroma). Freeze drying could inhibit bacteria growth but could not kill the spores in microbiological characteristics. Furthermore, freeze drying could maintain vitamin, mineral and active compound in the product instead of thermal drying process
\end{abstract}

Keywords : freeze drying, non thermal, sensory, chemistry, physic, microbiology

\begin{abstract}
Abstrak
Proses pengolahan makanan saat ini beralih dari proses termal ke proses non termal. Hal ini disebabkan karena proses non termal dapat mempertahankan mutu pangan didalamnya, meliputi sensorik dan nilai gizinya. Pengeringan beku/freeze drying merupakan metode pengeringan non termal yang dilakukan dengan menggunakan suhu yang rendah. Kandungan air didalam produk dalam fase air dibekukan menjadi fase padat (es) kemudian diubah menjadi fase udara dengan menggunakan prinsip sublimasi dengan mengendalikan suhu dan tekanannya. Terdapat perubahan karakteristik bahan pangan pada pengolahan keripik buah dengan metode freeze drying. Dari sifat fisik, meliputi perubahan sifat geometri, sifat mekanik, sifat optik dan sifat lainnya. Dilihat dari karakteristik sensorik proses pengeringan beku dinilai dapat mempertahkan sifat sensorik meliputi warna, rasa, tekstur dan aroma. Metode freeze drying dinilai dapat menghambat pertumbuhan bakteri, namun tidak dapat membunuh spora bakteri apabila dilihat dari karakteristik mikrobiologinya. Selanjutnya dari karakteristik kimia, diketahui metode freeze drying dinilai lebih baik dalam mempertahankan vitamin, mineral, dan bahan aktif di dalam produk dibanding dengan metode pengeringan dengan termal.
\end{abstract}

Kata Kunci :freeze drying, non termal, sensorik, kimia, fisik, mikrobiologi

\section{Pendahuluan}

Buah merupakan salah satu bahan pangan yang mempunyai peran penting untuk memenuhi kebutuhan zat gizi dan menjaga kesehatan manusia, khususnya dalam menyediakan sumber vitamin $\mathrm{C}$, vitamin $\mathrm{B} 1$ (thiamin), vitamin B3 (niacin), vitamin B6 (pyridoxine), asam folat, mineral dan serat [1].
Beberapa komponen fitokimia di dalam buah, seperti flavonoid dan vitamin $\mathrm{C}$ dinilai berperan sebagai antioksidan yang baik untuk mematikan zat-zat karsinogenik yang dapat mengaktifkan sel tumor dan kanker [1]. Selain itu kandungan antioksidan tersebut dinilai mampu mencegah penyakit sindrom metabolik pada manusia [1]. 
Meskipun demikian, buah merupakan salah satu bahan pangan yang mudah rusak (perishable food) sehingga tidak bisa disimpan dalam waktu yang lama. Hal ini berkaitan dengan karakteristik buah yang sangat disukai oleh bakteri [2]. Kandungan air yang tinggi, serta beberapa reaksi enzimatis yang dapat terjadi karena faktor luar, seperti oksigen $\left(\mathrm{O}_{2}\right)$, cahaya, maupun kelembaban udara menjadikan buah mudah untuk mengalami kerusakan [3]. Secara sensorik kerusakan buah dapat ditandai dari perubahan warna menjadi kecoklatan (browning), lembek, dan berbau tidak sedap [3].

Beberapa tahun terakhir, perkembangan pengolahan pangan beralih pada penggunaan teknik non termal yaitu teknik pengolahan pangan menggunakan panas dalam suhu yang relatif rendah dengan tujuan untuk mempertahankan mutu dari produk pangan yang dihasilkan [4]. Pengolahan jenis ini merupakan pengembangan dari teknik sebelumnya yaitu teknik termal, yang diketahui banyak menghilangkan kandungan zat gizi didalam buah [4].

Freeze drying atau yang sering disebut pengeringan beku merupakan salah satu contoh teknik pengolahan pangan dengan prinsip non termal [5]. Teknik ini dilakukan dengan menghilangkan kandungan air di dalam produk pangan melalui pembekuan, kemudian dilakukan sublimasi untuk mengubah fase padat (air) menjadi gas dengan mengendalikan suhu dan tekanan pada pengolahannya [5]. Pengeringan jenis ini dinilai mempunyai kelebihan dalam mempertahankan mutu dari produk, baik dari karakteristik sensorik, nilai gizi, fisik maupun kimia dibanding dengan pengeringan biasa yang menggunakan termal.

Keripik buah merupakan salah satu pangan yang dapat dihasilkan dari teknik pengolahan pengeringan beku. Teknik ini mampu menghasilkan produk keripik yang lebih baik dibandingkan dengan keripik dengan teknik lainnya, seperti vacuum deep frying, maupun penggorengan biasa apabila dilihat dari karakteristik sensorik, kimia, fisik, maupun mikrobiologi didalamnya [6].
Tujuan tulisan ini adalah untuk membahas perubahan karakteristik bahan pangan yang terjadi pada saat pengolahan keripik buah dengan metode pengeringan beku.

\section{Pembahasan}

\subsection{Keripik Buah}

Menurut SNI 01-4269-1996 Keripik buah merupakan makanan yang dibuat dari daging buah yang di masak, dipotong/disayat kemudian digoreng memakai minyak secara vakum dengan atau tanpa penambahan gula serta bahan tambahan makanan yang diijinkan [7]. Berbeda dengan definisi SNI tersebut, Keripik buah dengan metode freeze drying dibuat dengan metode yang berbeda [6].

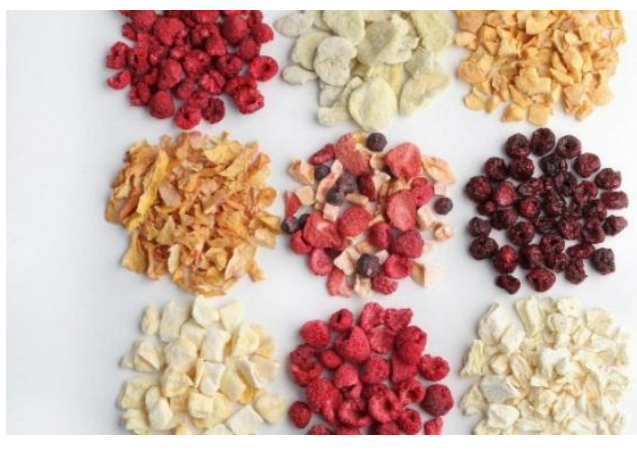

Gambar 1. Produk Freeze Drying

Keripik yang dihasilkan dari proses freeze drying umunya tidak digoreng dengan minyak, namun dikeringkan dengan suhu rendah pada kondisi vakum [6]. Selain itu, keripik buah dengan metode freeze drying dapat dibuat tanpa proses pemotongan ataupun penyayatan, khususnya untuk buah yang mempunyai ukuran kecil seperti strawberry dan anggur [6].

\subsection{Freeze Drying}

Freeze drying atau pengeringan beku merupakan teknologi pengeringan non termal dengan menggunakan suhu yang rendah [8]. Alat yang digunakan dalam teknologi pengolahan ini disebut freeze dryer [9].

Perbedaan pengeringan beku dengan teknologi pengeringan lain adalah mekanisme dalam menghilangkan kandungan air didalam bahan pangan. Penghilangan kandungan air dalam teknologi ini terjadi pada suhu yang rendah, melalui mekanisme sublimasi, 
langsung dari bentuk fase padat air (es) ke bentuk gas [8]. Produk pengeringan beku mempunyai beberapa kelebihan diantaranya meminimalkan penyusutan dan perubahan struktural, menghilangkan air lebih cepat, mempertahankan zat gizi dan perubahan minimal pada bau, rasa dan warna [8].

Bahan pangan yang sesuai untuk dilakukan proses pengeringan beku, diantaranya produk pangan dalam bentuk larutan, daging yang sudah diiris tipis, irisan buah/ sayuran, atau buah/sayuran utuh yang berukuran kecil [6].

\subsection{Prinsip}

Prinsip freeze drying yaitu mengeringkan bahan pangan dengan menghilangkan kandungan air didalamnya melalui proses sublimasi kandungan air didalam bahan pangan yang sudah menjadi beku kemudian diubah menjadi gas. Sublimasi dapat terjadi ketika tekanan dan suhu permukaan es dibawah triple point $\left(4,58 \mathrm{mmHg}, 0^{\circ} \mathrm{C}\right)$ [10].

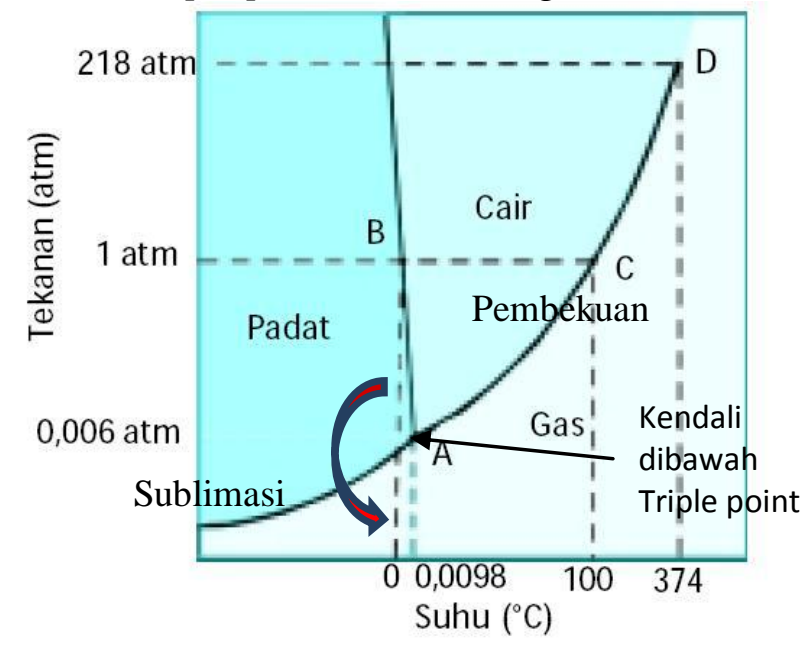

Gambar 2. Perubahan fase beku (air) menjadi gas melalui pengeringan beku

Terdapat 4 tahap dalam pengolahan pengeringan beku, diantaranya persiapan bahan pangan, pembekuan, pengeringan primer, dan pengeringan sekunder [9]. Tahap pertama dalam pengolahan freeze drying adalah persiapan bahan pangan. Pada pengolahan buah, umumnya buah yang mempunyai ukuran besar atau mempunyai kandungan air yang tinggi seperti buah melon, semangka, mangga, nanas, atau jeruk diperlukan proses pengirisan tipis. Proses ini bertujuan untuk mempercepat proses pengeringan. Namun buah yang berukuran kecil dan mempunyai kandungan air yang rendah seperti berry, anggur atau durian dapat langsung diolah. Selain itu, untuk memperpanjang masa simpan dapat pula ditambahkan bahan lain seperti bulking agent, stabilizer, pengawet atau larutan osmotik [9].

Selanjutnya tahap kedua yaitu pembekuan. Tahap ini dilakukan dengan menurunkan suhu freeze dryer hingga $-40{ }^{0} \mathrm{C}$ [9]. Pembekuan bertujuan untuk merubah fase air di dalam buah menjadi fase padat (es) [9].

Selanjutnya setelah dilakukan pembekuan, pada tahap ketiga adalah proses pengeringan. Proses ini dilakukan dengan dua tahap yaitu Pengeringan primer dan pengeringan sekunder. Pengeringan primer bertujuan untuk menghilangkan kadungan air dalam buah yang telah dibekukan melalui proses sublimasi dengan meningkatkan suhu sampai $0^{\circ} \mathrm{C}$ serta menurunkan tekanan dalam alat dibawah triple point yaitu $<4,58 \mathrm{mmHg}$, yang bertujuan agar gas yang terbentuk saat peningkatan suhu terbuang keluar. Setelah kandungan air telah keluar sekitar $95 \%$, kemudian dilakukan pengeringan sekunder dengan meningkatkan tekanan, dan suhu pada kondisi normal $35{ }^{\circ} \mathrm{C}$, dengan tujuan untuk mengkondisikan agar buah yang keluar dari alat tidak dalam kondisi beku atau dapat beradaptasi dengan suhu ruang [9].

Produk yang telah dihasilkan dari proses freeze drying umumnya aktivitas enzimnya tidak mati, namun dalam kondisi inaktif sementara, dikarenakan rendahnya kandungan air didalam produk. Dengan hal tersebut menjadikan produk freeze drying dapat teroksidasi, apabila terpapar oksigen $\left(\mathrm{O}_{2}\right)$. Oleh karena itu dalam pengolahannya produk yang telah dihasilkan harus segera dikemas menggunakan kemasan yang melindungi dari $\mathrm{O}_{2}$ seperti menggunakan bahan alumunium, atau plastik. Serta lebih baik menggunakan metode vacuum packaging 
agar meminimalisir udara di dalam kemasan [11].

\subsection{Perubahan Karakteristik Sifat Buah}

Perubahan karakterisitik keripik buah selama proses pengeringan beku meliputi perubahan karakteristik fisik, kimia, mikrobiologi, dan sensorik.

\subsubsection{Perubahan Karakteristik Fisik}

Perubahan karakterisitik sifat fisik keripik buah meliputi sifat geometri, dan struktural, sifat mekanis, sifat optik, sifat termal, dan sifat lainnya.

1) Sifat Geometrik, dan Struktural

a) Porositas dan tekstur

Porositas merupakan ukuran dari volume pori (ruang kosong) terhadap volume buah utuh. Parameter ini berpengaruh terhadap tekstur keripik yang dihasilkan. Porositas diukur dengan menggunakan scanning electron microscopy (SEM), yang diketahui pada keripik buah terjadi peningkatan porositas pada produk. Ini disebabkan karena saat pengeringan primer kandungan air didalam buah dikeluarkan sehingga meninggalkan ruang kosong/ pori di dalam buah. Peningkatan porositas berkaitan dengan kehilangan air selama proses pengeringan, diketahui pada pengeringan primer porositas meningkat $5 \mathrm{x}$ lebih tinggi dibanding pada pengeringan sekunder [1214].

Produk yang dihasilkan dari freeze drying memiliki porositas yang tinggi umumnya, dikarenakan menurunnya kandungan air dalam produk [15]. Porositas juga dipengaruhi oleh kecepatan pembekuan, semakin cepat pembekuan maka semakin besar porositas yang dihasilkan [15].

b) Kondisi Permukaan

Pada proses pembekuan $-40 \quad{ }^{0} \mathrm{C}$ dengan nitrogen mengakibatkan timbulnya kerak/lapisan pada permukaan buah, kondisi ini mengakibatkan terhambatnya perpindahan massa pada saat sublimasi, ketika terjadi transisi fase dari padat (es) ke gas di dalam bahan, mengakibatkan keretakan (crack) serta collapse struktural pada permukaan bahan pangan [16].

c) Densitas

Terdapat 3 jenis densitas pada produk pengeringan beku yang diamati, diantaranya apparent density, bulk density dan real density. Terdapat penurunan pada apparent density dan bulk density saat pengolahan dengan pengeringan beku, ini disebabkan karena apparent density dan bulk density berhubungan linier dengan kadar air produk, sehingga pada pengolahan dapat menyebabkan penurunan apparent density dan bulk density. Disisi lain terdapat peningkatan real density akibat adanya konsentrasi karbohidrat yang mempunyai densitas lebih tinggi dibanding dengan air [12].

d) Penyusutan/Shrinkage

Pada awal proses freezer drying derajat penyusutan/ shrinkage cenderung lebih rendah, ini disebabkan karena terbentuknya es, sehingga kadar air didalam produk tidak begitu banyak menyusut. Namun pada saat terjadinya pengeringan melalui sublimasi diketahui terdapat nilai peyusutan yang lebih tinggi disebabkan karena adanya kehilangan kadar air [17]. Konsekuensi dari meningkatnya shrinkage mengakibatkan penurunan ukuran dan berat produk keripik buah dibanding dengan buah segar [17].

e) Keruntuhan struktural/ Collapse

Collapse adalah istilah yang digunakan untuk menggambarkan terjadinya kehilangan struktural pada bahan pangan. Kondisi ini dapat digambarkan dengan adanya pengentalan aliran karena pengurangan viskositas diuar suhu transisi gelas [16]. Selain itu collapse juga dapat didefinisikan dengan penurunan volume atau peningkatan kepadatan masing masing buah yang dapat diamati dengan terjadinya penyusutan pada produk kering [18]. Produk yang mengalami collapse lebih keras, memiliki penurunan volatil dan 
meningkatkan rehidrasi. Kondisi ini dapat disebabkan karena meningkatnya porositas dan kapasitas rehidrasi selama proses pengolahan [18].

Pada keripik buah terjadi keruntuhan struktural/ collapse yang disebabkan karena meningkatnya porositas akibat penurunan kadar air selama proses. Kondisi ini mengakibatkan terjadinya penurunan volume dan peningkatan kepadatan, sehingga keripik buah memiliki tekstur yang lebih keras dibandingkan dengan buah segar. Terjadinya collapse dapat diminimalisir dengan melakukan persiapan awal dengan menambahkan sukrosa, atau etanol untuk mempercepat proses pengeringan beku, sehingga dapat melindungi terjadinya collapse [19]. Meskipun demikian, produk dengan pengeringan beku dinilai lebih sedikit mengalami collapse dibanding dengan produk buah kering dengan pengeringan termal[18].

2) Sifat Mekanis

a) Reologi

Perilaku reologi suatu fluida dipengaruhi oleh beberapa faktor, terutama gaya antar molekul dan interaksi air terlarut yang membatasi pergerakan partikel pada level molekuler [20]. Perubahan suhu dan konsentrasi dapat menyebabkan perubahan signifikan pada gaya antarmolekul. Reologi dapat dilihat melalui shear rate dan viskositas [21].

Pada pengolahan keripik buah terdapat perubahan sifat mekanis bahan yang dapat dilihat dari viskositasnya. Semakin tinggi viskositas dalam buah maka dapat menurunkan terjadinya keruntuhan struktural. Pada proses pembekuan viskositas air meningkat karena air membeku, namun ketika proses pengeringan, air dalam pangan mengalami pencairan sehingga menjadikan viskositas menurun [16].

3) Sifat Optik

a) Warna

Warna merupakan karakteristik fisik bahan pangan yang paling awal dan mudah diamati dibandingkan karakteristik lainnya. Pada buah yang telah dikeringkan menggunakan freeze dryer umumnya akan mengalami perubahan warna. Ini dikarenakan pada saat proses pengeringan terjadi kehilangan pigmen warna pada buah bersamaan dengan kandungan air, contohnya adalah berkurangnya pigmen warna antosianin pada strawberry [22].

Tinggi rendahnya intensitas warna juga dipengaruhi oleh kecepatan dalam pembekuan, hal ini dikarenakan kecepatan pembekuan berpengaruh pada terbentuknya pori pori yang lebih kecil sehingga dapat meningkatkan penyebaran cahaya dibanding dengan pori pori yang lebih besar [24].

Pada proses penyimpanan, produk buah dengan pengeringan beku sangat rentan terhadap oksigen yang dapat mengakibatkan oksidasi. Pemberian sulfur dioksida pada penanganan buah dinilai dapat menurunkan oksidasi asam askorbat pada buah. Selain itu, juga dapat mencegah pencoklatan pada buah [25]. Selain itu menurut penelitian yurdugu tahun 2007 menyebutkan buah ditambahkan larutan basa lebih baik dalam mempertahankan warna dibandingkan dengan penambahan asam, dikarenakan kondisi basa dapat menurunkan degradasi pigmen antosianin[23].

4) Sifat Termal

a) Suhu Transisi Gelas

Pada pengolahan keripik buah terjadi peningkatan suhu transisi gelas, yang disebabkan penurunan kadar air dalam buah selama proses [26].

5) Sifat Lain-lain

a) Kapasitas Rehidrasi

Kapasitas rehidrasi adalah kemampuan untuk menyerap kembali air yang hilang selama proses pengeringan (dehidrasi). Kapasitas retensi adalah kemampuan untuk menyerap dan menahan air terhadap kekuatan mekanink. Meskipun keripik buah umumnya tidak memerlukan proses rehidrasi dalam penyiapannya, namun 
diketahui bahwa produk keripik buah juga mampu mengalami rehidrasi. Selama proses pengeringan terdapat peningkatan porositas dalam produk, dengan meningkatnya porositas tersebut mengakibatkan peningkatan kapasitas rehidrasi dikarenakan adanya pori pori pada produk yang dapat diisi oleh air. Kapasitas rehidrasi tergantung pada ukuran, geometri, komposisi, kadar air dan porositas buah [26].

\subsubsection{Perubahan Karakteristik Kimia}

Perubahan kimiawi yang terjadi selama proses freeze drying diantaranya terjadi pada senyawa fenolik, asam askorbat dan beta karoten. Senyawa fenolik termasuk dalam senyawa antioksidan dengan jumlah terbanyak dalam produk buah secara umum. Aktivitas antioksidan dan total senyawa fenolik pada produk dengan freeze drying diketahui menurun selama proses pengolahan [29,30]. Diketahui bahwa buah segar memiliki kandungan total senyawa fenolik lebih tinggi dibandingkan buah yang diproses melalui metode freeze drying [26].

Senyawa asam askorbat atau lebih dikenal sebagai vitamin $\mathrm{C}$ dinilai rentan dengan pemanasan. Senyawa tersebut dapat dengan mudah teroksidasi menjadi senyawa asam dehidroaskorbat yang dapat bereaksi membentuk polimer yang kehilangan fungsinya. Dengan menggunakan proses freeze drying, degradasi kandungan vitamin $\mathrm{C}$ dapat diminimalisir dibandingkan dengan proses pengeringan konvensional. [26,31]. Retensi senyawa vitamin $\mathrm{C}$ disebabkan karena proses pengeringan dilakukan pada suhu rendah. [26]

Senyawa beta karoten atau lebih dikenal sebagai pro vitamin A ditemukan dalam membran lipid atau vakuola dari sayuran hijau atau buah yang bewarna kuning dan orange. Proses freeze drying dinilai kurang baik dalam melindungi kehilangan beta karoten selama proses. Hal ini dikarenakan terjadinya collapse selama proses mengakibatkan penetrasi oksigen yang dapat mengoksidasi beta karoten tersebut [31].
Diantara perubahan biokimia yang terjadi, reaksi pencoklatan dan oksidasi lipid adalah yang paling sering ditemukan. Reaksi pencoklatan ini berdampak pada penampakan, flavor dan nilai gizi. Pencoklatan tidak dikehendaki pada buah, sayuran dan pangan yang dikeringkan karena menghasilkan flavor yang menyimpang dan menyebabkan peruqbahan tekstur. Efek dari pencoklatan dapat menurunkan nilai gizi dan kelarutan. Kecepatan reaksi pencoklatan bergantung suhu pengeringan, $\mathrm{pH}$, kadar air produk, suhu pemanasan, konsentrasi dan sifat reaktan. Dalam kaitannya dengan freeze drying, pencoklatan terjadi karena reaksi enzimatis.

Oksidasi lipid bertanggung jawab terhadap ketengikan, terjadinya rasa dan aroma yang menyimpang dan kehilangan lemak, vitamin dan pigmen di buah dan sayuran. Faktor yang mempengaruhi laju oksidasi meliputi kadar air, tipe substrat (asam lemak), jangkauan reaksi, kandungan oksigen, suhu, keberadaan logam, keberadaan antioksidan alami, aktivitas enzim, sinar ultraviolet, kandungan protein, kandungan asam amino bebas dan reaksi kimia lainnya.

Produk dengan metode freeze drying dinilai rentan terhadap reaksi oksidasi, hal ini dikarenakan porositas produk yang tinggi berpengaruh pada laju reaksi oksidasi. [27] Namun dengan kemasan polietilen vakum, laju reaksi dapat diminimalisir. Produk yang disimpan dengan kemasan polietilen vacuum dapat bertahan setelah penyimpanan 6 bulan tanpa ditemukan perubahan rasa, warna, tekstur dan aroma secara signifikan [32]

\subsubsection{Perubahan Karakteristik Sensorik}

Terdapat 4 parameter sensorik yang digunakan untuk menilai perubahan sensorik pada buah, yaitu warna, rasa, aroma dan tekstur. Perubahan dapat dilihat pada tabel 1. 
Warna merupakan salah satu karakteristik sensorik, dan dianggap sebagai indikator kualitas dari pangan kering. Faktor yang berkaitan dengan warna diantaranya pencahayaan, dekorasi, ukuran dan bentuk. Proses freeze drying cenderung dapat mempertahankan warna dibandingkan dengan produk dengan menggunakan metode pengeringan lainnya.

Buah stroberi yang diolah dengan proses pengeringan beku pada suhu dibawah $-50^{\circ} \mathrm{C}$ dapat mempertahankan warna dibandingkan dengan suhu diatas $-50^{\circ} \mathrm{C}$ Efek ini dapat disebabkan akibat konsentrasi zat yang dilarutkan lebih besar dan akibat $\mathrm{pH}$ yang berasal dari antosianin. Penambahan
Senyawa volatil dalam buah selama proses terjebak di dalam daerah mikro dari bahan yang kering. Kehilangan senyawa volatil disebabkan oleh penyerapan air ke dalam bahan yang kering [27].

Tekstur merupakan salah satu karakteristik sensori dan termasuk sifat penting dari produk pangan. Faktor yang berkaitan dengan tekstur diantaranya kadar air, komposisi, varietas, $\mathrm{pH}$, tingkat kematangan dan dimensi sampel [27].

\subsubsection{Perubahan Karakteristik Mikrobiologi}

Pada pengolahan buah melalui freeze drying, terdapat perubahan pada karakteristik mikrobiologinya. Perubahan karakteristk mikrobiologi meliputi bakteri, kapang dan

Tabel 1. Karakteristik buah sebelum dan sesudah pengeringan beku [27]

\begin{tabular}{|c|c|c|c|}
\hline Buah & Karakteristik & Sebelum Pengolahan & Sesudah Pengolahan \\
\hline \multirow[t]{4}{*}{ Pisang } & Warna & $\begin{array}{l}\text { kulit berwarna kuning cerah dan } \\
\text { daging berwarna putih lembut }\end{array}$ & daging berwarna kuning keputihan \\
\hline & Tekstur & $\begin{array}{l}\text { lembut, tidak ada kerusakan akibat } \\
\text { memar dan lainnya }\end{array}$ & $\begin{array}{l}\text { renyah dan tekstur lembut, tidak mudah } \\
\text { hancur }\end{array}$ \\
\hline & Rasa & manis dan lembut & manis didalam, flavor alami tetap bertahan \\
\hline & Bentuk & dipotong melingkar & sedikit menyusut \\
\hline \multirow[t]{4}{*}{ Apel } & Warna & $\begin{array}{l}\text { kulit berwarna merah, daging } \\
\text { berwarna putih, dan biji berwarna } \\
\text { hitam }\end{array}$ & $\begin{array}{l}\text { kulit berwarna merah, halus, daging } \\
\text { berwarna putih dengan sedikit kecoklatan } \\
\text { dibagian permukaan }\end{array}$ \\
\hline & Tekstur & kulit halus, daging padat dan renyah & tekstur lembut, halus, padat, kenyal \\
\hline & Rasa & flavor manis dan berair & $\begin{array}{l}\text { manis didalam, sedikit asam dan flavor } \\
\text { alami tetap bertahan }\end{array}$ \\
\hline & Bentuk & daging berbentuk bulat & bentuk tetap dipertahankan \\
\hline \multirow[t]{4}{*}{ Kiwi } & Warna & $\begin{array}{l}\text { kulit berwarna coklat kehijauan pucat, } \\
\text { daging berwarna hijau cerah dan biji } \\
\text { berwarna hitam }\end{array}$ & daging dan biji berwarna hijau keputihan \\
\hline & Tekstur & berserat dan berbulu halus & berserat dan mudah hancur dilidah \\
\hline & Rasa & manis dan menyerupai jeruk & $\begin{array}{l}\text { sangat asam, menyerupai jeruk, sedikit } \\
\text { manis, tetapi flavor alami tetap bertahan }\end{array}$ \\
\hline & Bentuk & dipotong melingkar & bentuk tetap dipertahankan \\
\hline
\end{tabular}

biopolymer seperti gum arab juga dapat melindungi warna buah dan juga membuat renyah produk snack[28].

Aroma merupakan salah satu karakteristik sensori. Dalam buah segar terdapat senyawa volatil yang berperan dalam pembentukan warna, diantaranya yaitu senyawa ester, alkohol, terpen, aldehida, karbonil, asam, fenol, hidrokarbon, sulfur dan glukosinoat. Kandungan senyawa volatil berubah seiring dengan tingkat kematangan buah. khamir.

Jumlah bakteri selama pengolahan mengalami penurunan, ini disebabkan karena proses pembekuan beku mengakibatkan penurunan kadar air di dalam buah dan aktivitas air, kondisi ini menyebabkan kerusakan DNA dan RNA, denaturasi protein, perubahan membran sitoplasma dan kerusakan dinding sel bakteri, yang berkaitan dengan peningkatan konsentrasi asam yang dapat merusak sel bakteri [33]. 
Namun, disisi lain terdapat senyawa yang ditemukan dalam buah dan sayuran yang dapat meningkatkan kemampuan bertahan hidup mikroorganisme selama dehidrasi, seperti, sukrosa dan gula lain, polipeptida, polialkohol, asam amino, gliserol, dan asam karboksilat yang telah terbukti meningkatkan kemampuan bertahan hidup bakteri. Penurunan aktivitas air bukanlah satu satunya faktor yang dapat mempengaruhi jumlah bakteri. Faktor lain seperti perubahan tekanan atmosfer, konsentrasi $\mathrm{CO}_{2}$ atau $\mathrm{N}_{2}$ atau gelombang elektromagnetik juga memberikan pengaruh pada jumlah bakteri di dalam produk $[34,35]$.

Selama proses freeze drying, diketahui kapang dan khamir tidak dapat tumbuh [36]. Namun proses pengeringan beku tidak dapat membunuh spora dari kapang dan khamir didalam buah. Disisi lain terjadinya penurunan kadar air dan peningkatan konsentrasi asam, serta antioksidan di dalam buah dapat menghambat pertumbuhan dari kapang dan khamir [37].

\section{Kelebihan dan Kelemahan}

Kelebihan proses freeze drying pada bahan pangan adalah terhindar dari kerusakan kimiawi dan mikrobiologis, sensorik, daya rehidrasi baik dan kandungan gizi, sehingga cocok untuk produk yang rentan terhadap proses panas.

Kelemahan proses pengeringan beku adalah biaya mahal karena konsumsi energi yang tinggi, waktu dan proses yang lama.

\section{Kesimpulan}

Freeze drying atau pengeringan beku merupakan salah satu teknik pengolahan non termal yang bertujuan untuk meningkatkan masa simpan produk. Keripik buah yang dihasilkan melalui freeze drying dinilai lebih baik dari segi sensorik, kimia, maupun fisika dibanding dengan pengolahan termal, namun pengolahan jenis ini dinilai belum mampu membunuh spora mikrobiologi yang berada di dalam buah. Teknologi ini masih jarang digunakan karena mempunya biaya yang mahal untuk investasi, dan operasionalnya.

\section{Saran}

Diperlukan penelitian yang mengkaji terkait perubahan karakteristik bahan pangan lain, seperti daging, sayur atau biji bijian lain seperti kopi dengan menggunakan teknologi freeze drying

\section{Daftar Pustaka}

1. Oguntibeju OO, Truter JE, Esterhuyse JA. The Role of Fruit and Vegetable Consumption in Human Health and Disease Prevention, Diabetes Mellitus - Insights and Perspectives, 2013.

2. Barth M, Hankinson TR, Zhuang H, Breidt F. Microbiological Spoilage of Fruits and Vegetables. Compendium of the Microbiological Spoilage of Foods and Beverages, 2009.

3. Rawat S. Food Spoilage: Microorganisms and their prevention. Asian Journal of Plant Science and Research, vol. 54, no. 47-56, 2015.

4. Moses JA, Norton T, Alagusundaram K, Tiwari BK. Novel Drying Techniques for the Food Industry, Food Engineering Reviews, vol.6 no.3, pp.43-55, 2014.

5. Liapis AI, Bruttini R. Freeze Drying : Handbook of Industrial Drying (edited by A.S. Mujumdar).259-83.;2007.

6. Hariyadi P. Freeze Drying Technology: for Better Quality \& Flavor of Dried Products, FoodRev, vol.VIII, no.2, 2013.

7. BSN. SNI 01-4269-1996 Keripik nangka. Badan Standarisasi Nasional Republik Indonesia.1996.

8. Gaidhani KA, Harwalkar M, Bhambere D, Nirgude PS. Lyophilization / Freeze Drying A Review, WJPR, vol. 4, no.8, 2015.

9. Shukla S. Freeze Drying Process: A Review, IJPSR, vol.2, no.12, 2011.

10. Nireesha GR, Divya L, Sowmya C, N.Venkateshan, Babu MN, V.Lavakumar. Lyophilization/Freeze Drying - An Review. IJNTPS, vol.3, no.4, 2013.

11. Wolfe CW. Packaging Freeze-Dried Foods. Sage Journal, vol.5, no.1, 1964.

12. Marques LG, Prado MM, Freire JT Rehydration characteristics of freeze-dried tropical fruits. Food Science and Technology, 2009

13. Liliana S-C, Diana PV-M, Alfredo AA. Structural, physical, functional and 
nutraceutical changes of freeze-dried fruit. African Journal of Biotechnology, vo.14, no.6, pp.442-50, 2015.

14. Oikonomopoulou VP, Krokida MK, Karathanos VT. The influence of freeze drying conditions on microstructural changes of food products. Procedia Food Science, vol.1, 2011.

15. Ceballos AM, Giraldo GI, Orrego CE. Effect of freezing rate on quality parameters of freeze dried soursop fruit pulp. Journal of Food Engineering, vol.111, no. 2, pp. 360-365 , 2012.

16. Harnkarnsujarit $\mathrm{N}$, Charoenrein S. Influence of collapsed structure on stability of $\beta$ carotene in freeze-dried mangoes. Food Research International, vol.44, no. 10, 2011.

17. Yan Z, Sousa-Gallagher MJ, Oliveira FAR. Shrinkage and porosity of banana, pineapple and mango slices during air-drying. Journal of Food Engineering, vol.84, no.3, 2008.

18. Cui Z-W, Li C-Y, Song C-F, Song Y. Combined Microwave-Vacuum and Freeze Drying of Carrot and Apple Chips. Drying Technology. vol.26, no.12, pp.1517-23,2008.

19. Alves CCdO, Resende JV, Prado MET, RibeiroCruvine RS. The effects of added sugars and alcohols on the induction of crystallization and the stability of the freezedried peki (Caryocar brasiliense Camb.) fruit pulps. LWT Food Sci. vol.43, no.6, pp.934-41, 2010.

20. Castilhos d, Betiol, Carvalho d, Telis-Romero. Experimental study of physical and rheological properties of grape juice using different temperatures and concentrations. Part II: Merlot. Food Res Int, vol.105, pp.905-912, 2018.

21. Shamsudin R, Ling CS, Adzahan NM, Daud WRW. Rheological properties of ultravioletirradiated and thermally pasteurized Yankee pineapple juice. J Food Eng Rev, vol.116, no. 2, pp. 548-553, 2013.

22. Shishehgarha F, Makhlouf J, Ratti C. FreezeDrying Characteristics Of Strawberries. Drying technology, vol.20, no.1, pp.131-45 , 2002.

23. Yurdugu S. An evaluation of the retention of quality characteristics in fresh and freezedried alpine strawberries. Food Science, vol. 43, pp. 865-870, 2008.

24. Ceballos AM, Giraldo GI, Orrego CE. Effect of freezing rate on quality parameters of freeze-dried soursop fruit pulp. J Food Eng Rev. vol.111, no.2, 360-365, 2012.

25. Draudt HN, Huang I-Y. Effect of Moisture Content of Freeze-Dried Peaches and Bananas on Changes during Storage Related to Oxidative and Carbonyl-Amine Browning. $J$ Agric Food Chem. vol.14, no.2, pp.170-176, 1966.

26. Serna-Cock L, Vargas-Muñoz DP, Aponte AA. Structural, physical, functional and nutraceutical changes of freeze-dried fruit. African Journal of Biotechnology, vol. 14, no. 6, pp. 442-50, 2015.

27. Valentina V, Pratiwi A, Hsiao P, Tseng H, Hsieh J, Chen C. Sensorial Characterization of Foods Before and After Freeze-drying. Austin Food Sci, vol.1, no.6, 2016.

28. Martínez-Navarrete N, Salvador A, Oliva C, Camacho MM. Influence of biopolymers and freeze-drying shelf temperature on the quality of a mandarin snack. LWT, vol.99, pp.57-69, 2019.

29. Rahman, Das R, Hoque, Zzaman. Effect of freeze drying on antioxidant activity and phenolic contents of Mango (Mangifera indica). International Food Research Journal, vol.22, no.2, pp.613-617, 2015.

30. Priyanka P, Rajitha S, Lloyd T, Martha V. Effect of Drying Techniques on Antioxidant Capacity of Guava Fruit. Food and Nutrition Sciences, vol.7, pp.544-554, 2016.

31. Vinod K, Suneetha K, Sucharitha K. Freeze Drying- a Novel Processing for Fruit Powders. International Journal of Food and Nutritional Science, vol.1, no.1, 2012.

32. Djekic I, Tomic N, Bourdoux S, Spilimbergo $\mathrm{S}$, Smigic N, Udovicki B, et al. Comparison of three types of drying (supercritical CO 2 , air and freeze) on the quality of dried apple Quality index approach. Lwt, vol.94, pp.6472, 2018.

33. Morgan CA, Herman N, White PA, Vesey G. Preservation of micro-organisms by drying; a review. Journal of microbiological methods. vol. 66, no.2, pp.183-189, 2006.

34. Syamaladevi RM, Tang J, Villa-Rojas R, Sablani S, Carter B, Campbell G. Influence of Water Activity on Thermal Resistance of Microorganisms in Low-Moisture Foods: A Review. Comprehensive Reviews in Food Science and Food Safety. vol.15, no.2, pp.353-370, 2016. 
35. Bourdoux S, Li D, Rajkovic A, Devlieghere F, Uyttendaele M. Performance of Drying Technologies to Ensure Microbial Safety of Dried Fruits and Vegetables. Comprehensive Reviews in Food Science and Food Safety. vol.15, no.6, 2016.

36. Passamani FR, Hernandes T, Lopes NA, Bastos SC, Santiago WD, Cardoso M, et al. Effect of temperature, water activity, and $\mathrm{pH}$ on growth and production of ochratoxin A by Aspergillus niger and Aspergillus carbonarius from Brazilian grapes. Journal of food protection. vol. 77, no.11, 2014.

37. Yu J. Impacts of Different Drying Methods on Mold Viability and Ochratoxin A Content of Grape Pomace. International Journal of Applied Agricultural Sciences. vol.4, no.2, pp.35-40, 2018. 